\title{
An Analysis of Local Legislation of the Village-level River Extension System- -A Case Study of the Drafting of Village-level River Regulations in Ya'an
}

\author{
Li Feiming ${ }^{1}$, Liu Shuang ${ }^{2}$, Zhao Luran ${ }^{3}$ \\ ${ }^{1}$ Law School, Sichuan Agricultural University, Ya’an, China \\ ${ }^{2}$ Law School, Sichuan Agricultural University, Ya'an, China \\ ${ }^{3}$ Law School, Sichuan Agricultural University, Ya'an, China \\ 847796447@qq.com \\ Li Feiming
}

Keywords: Environmental Governance, Village-level River Extension System, Local Legislation

\begin{abstract}
The village-level river chief system is a system innovation in the implementation of the four-level river chief system in the provinces, cities, counties (districts) and townships of the state. Local legislation is a necessary prerequisite and legal basis for practice. At village-level river chief system of local legislation drafting a certain progress, also appeared a series of legal problems need to solve, such as the village-level river chief's legal position is unclear, and the administrative organs of the legal relationship is unknown, the researchers selected, fallback mechanism is not sound, etc. Based on further thinking and practice of law, where village-level river chief system exploration of "rule by law", in order to achieve the ultimate goal of comprehensive environmental governance.
\end{abstract}

Ecological environmental protection is one of the nineteen major focuses. In 2016, China has promoted the river chief system throughout the country. Ya'an of Sichuanprovince Ya'an City, launched the river chief system in 2017.In the process of implementation of river chief system, considering the importance and particularity ,the legislator of ya'an drafted the "management regulations of the river chief system in ya'an" (hereinafter to be as the Regulations), try to set up the river chief system work mechanismin the local legislation. In this paper, take the drafting of the regulations as the entry point to explore the local legislative path of the Village-level river chief system.

\section{Existing problems in legislative drafting}

\subsection{Unclear legal positioning of village river chief}

The newly amended Law of the People's Republic of China on the Prevention and Control of Water Pollution clarifies the legal status of the provincial, municipal, county and township-level river chief. The newly revised "Regulations on Environmental Protection Management of Sichuan Province" further clarified: "Encourage the establishment of a village-level river system." The upper law provides a legal basis for the establishment of the village-level river chief system. The river-level and above-mentioned river chiefs and the "village-level river chief" are both part of China's "river chief system", and their management responsibilities are also roughly the same, but from a legal perspective, the two are essentially different.

\subsubsection{The legal basis for establishment is different.}

Township level and above of the river chief system established, mainly on the basis of article 5 of the law on the prevention and control of water pollution of the provincial, that establish theriver chief system at the province, city, county and township level. The relationship between local laws and central legislation is "sub-law" and "mother law". The local regulations themselves have the 
characteristics of dependence mainly for the implementation of the central legislation, and they have the autonomy characteristics due to the inherent local legislative authority ${ }^{1}$.Specific to Sichuan Province, is based on the "Sichuan Province Environmental Protection Regulations." It is the lower law of the former and has a lower legal effect.

\subsubsection{Different subject identities.}

According to "Opinions", the river chiefs at the township level and above are all cadres of the party and government organs and are civil servants. The village-level river chief does not have the status of a civil servant, which is significantly different from the former. Both civil servants and river chiefs have the property of "maintaining public interest". However, the village-level river chief has not obtained the civil servant status for obtaining the work of the river chief. Therefore, the identity of the two is still completely different.

\subsubsection{The legislative focus of village-level river chief system is different}

According to "Opinions" 2 , the river chiefs at the township level and above are all the leadership. The village river chiefs are the executors. Because there is a difference in the powers between the river chiefs at the township level and above and the river level of the village level, the legislative focus of the village-level river system is inevitably different from the former.

\subsection{The legal relationship between village river chiefs and village (residential) committees is unclear}

The village-level river system is theoretically attributed to the"river chief system", a large mechanism system. Despite the current practice, the work of the village-level river chief was temporarily distributed to the village (residential) committee cadres or ordinary village (residents). The village-level river chief does not necessarily have a affiliation with the village committee. It is obvious that the village committee cannot naturally form a legal affiliation with the village-level river chief.

\subsection{The generation of village river chief is unknown}

In local legislation, the way in which village-level rivers are produced is an important issue. As mentioned above, village-level river chiefs are independent of the working status of village (residential) committee cadres and their establishment methods need not be equivalent to village (residential) committee cadres. It is necessary to design personnel according to the working characteristics of the river level chief at the grassroots level and the combination of grassroots management methods.

Because of the aforementioned problems in the establishment of village-level river chief system, the source of its responsibilities is not clear. On the one hand, the village river chiefs not supervised by thevillage (r) commission. On the other hand, if the rights and obligations of the village-level river chief are clarified by signing an agreement, the agreement will be controversial in the definition of nature.

\subsection{The village-level river system lacks a long-term working mechanism}

Establish mechanism of river chief system need to consider the long-term construction work. Local legislation creating the village river system tend to focus on giving the village river long function. If neglect the construction of the mechanism, the system may be so incomplete that difficult to keep for a long time or runenduring and efficiently.

\footnotetext{
${ }^{1}$ Hu yuhong.Try to talk about the legal status of the standard--Combined with status problem between the administrative regulations and local regulations, Chinese Legal Science.vol.03,2004.

${ }^{2}$ Adhere to party and government leadership and departmental linkage. We will establish and improve a responsibility system with the party and government leadership responsibility as the core, clarify the responsibilities of the rivers at all levels, strengthen work measures, coordinate the strengths of all parties, and form a work pattern of first-level and first-level implementation.
} 


\section{Try to explore the local legislative path}

\subsection{To clarify the legal position of village river leaders}

River chief system is a special measure of river governance in China. Only by clarifying the legal identity of river chief can the responsibilities and rights of all subjects in river governance be clarified. ${ }^{3}$ As an extension of the four-level river chief system in cities, counties and counties (districts), the village-level river chief system legislation must also clarify its legal position and solve the realistic predicament of the village-level river chief system. Although at the end of 2016 issued the "opinions" is as part of the normative documents, and did not reach the level of law, only founded according to the "Opinions" the village-river chief system is obviously insufficient in law. ${ }^{4}$ Most areas still mainly administrative command, external force, has the characteristics of temporary, intrusive, many river chiefs lack of lasting power within. ${ }^{5}$ For this problem of village river chief's legal position is unclear, On the one hand, the law-making of the village-level river chief system must implement the relevant national policies and implement the spirit of the Opinions, which is consistent with the Opinions. On the other hand, the legislation of the village-level river chief system must strictly follow the provisions of the "Legislation Law" and grasp the legal hierarchy relationship with the relevant superior law.

\subsection{To clarify the legal relationship between village river chiefs and village (residential) committees and sub-district offices}

Clarify the legal relationship between village river chiefs and village (residential) committees and sub-district offices that is the former way to clear the source of the village river chief's responsibilities. And it is a necessary consideration before constructing the supervision model of village-level river chief system. village-level river chief management or supervision shall be borne by the superiordirectly ,it's clearly more appropriate. In the draft the "regulations", a parallel "support" relationship was established between village river heads and village (residential) committees. The village (residential) committee plays an auxiliary coordinating role in the selection and appointment of village river leaders, and to support and coordinate the functions of village river leader. On the whole, the village (residential) committee and the sub-district office only form a working cooperative relationship with village river chiefs.

\subsection{To clarify the source of responsibilities of village level river chiefs}

Village level river chiefs'duty source is the responsibility of village - level river chief should be taken into account. In view of the village-level river chiefs because of the status of civil servants, it is not appropriate to adopt administrative order. There are may be given to the signing of agreement between local administrative organs and village river heads. According to the supreme people's court on the applicable < administrative procedure law of the People's Republic of China >, the explanation of some issues (hereinafter referred to as the " applicable to explain " ), article 11 of the definition of administrative agreement ${ }^{6}$.According to the provisions of this article, it may be made clear that the agreement between the village level river chief and the corresponding administrative authority shall be referred to as the administrative agreement in the applicable interpretation. Although it is not necessary to specify the nature of local legislation from the perspective of legislative technical specifications, it is of practical significance to clarify this issue from the theoretical perspective.

\footnotetext{
${ }^{3}$ Chen Meixuan. From River Governor System to River Governor Management: On the Theoretical Basis and Practical Innovation of the River Governor Management, journal of central south university of forestry \& technology,vol.02,pp.6-11,2018.

${ }^{4}$ Chen Meixuan. From River Governor System to River Governor Management: On the Theoretical Basis and Practical Innovation of the River Governor Management, journal of central south university of forestry \& technology,vol.02,pp.6-11,2018.

${ }^{5}$ Zhu Mei. On the Development and Promotion of River Governor System, Environmental Protection,vol.Z1,2017.

${ }^{6}$ The supreme people's court on the applicable $<$ administrative procedure law of the People's Republic of China $>$, the explanation of some issues (hereinafter referred to as the "applicable to explain”), article 11 of the definition of administrative agreement the administrative organ to realize public interests or administrative management objectives, within the scope of the statutory duties, conclude the consultation with citizens, legal persons or other organizations with content of the agreement, the rights and obligations on the administrative law belongs to "Administrative procedural law” paragraph 11 of article 12 (1) the administrative agreement.
} 
Specific to the village-level river chief selection method, according to the " Regulations " draft design. Village-level river chiefs are recommended by the village (neighborhood) committee, village (neighborhood) self-recommendation, and township (town) people's governments and sub-district offices determine the method. The town government-level administrative agency has the final decision, and the mode of production of the village-level rivers lacks complete democracy. However, it is reasonable to consider the comprehensive efficiency factors in order to avoid the procedure being too cumbersome due to avoiding the use of election methods. The selection and retreat system of the personnel is not complete in the legislation.

\subsection{Building a complete system}

The local legislation of the village-level river chief system needs to build a complete system. Social governance work is not enough for the state organs themselves. It depends on the support of the whole people. This requires relying on the support of the people ${ }^{7}$.This is even more true in the area of environmental governance. An important purpose of establishing a village-level river chief system is to realize "complementation of the short board" in which the functional departments and grass-roots people have advantages and disadvantages in terms of administrative management authority and cutting-edge news transmission, so as to truly realize the management of river eco-environment. In the supervision and assessment mechanism, local legislation often neglecting the role of the village-level river-length as a grass-roots "supervisor", and playing an important role in the social supervision work of the relevant administrative departments. In addition, the "rule of law" of the river system needs to rely on the participation of the public as the main body of society. But the public's expression of environmental interests is not sufficient ${ }^{8}$.The local legislation of the village-level river chief system not only needs to rationalize the coordination and cooperation between the administrative organs and the village-level river chiefs, but also grasps the principle of public participation. In addition, when local legislation establishes a village-level river chief system, it is necessary to combine the local conditions and establish an assessment and incentive mechanism that is different from the river level chief of the township level and above according to the special nature of the village-level river chief. While realizing the guarantee of basic materials, it will play a role together with the training mechanism to achieve long-term, orderly and benign operation of the village-level river chief system.

\section{Conclusion}

In the local practice of village-level river chief system, it is necessary to stick to legislation first and guarantee the implementation of river chief system with legal system, which is also a concrete manifestation of the rule of law. Local legislation on village-level rivers. The legal system with normative and stable requirements clearly defines and defines the relationship between the powers, rights, and responsibilities of the mayor and related river governance subjects. It can therefore avoid the abuse of power by the river. And protect the rights of related stakeholders and to achieve the ultimate goal of comprehensive management of river ecological environment.

\section{References}

[1] Hu yuhong. Try to talk about the legal status of the standard--Combined with status problem between the administrative regulations and local regulations, Chinese Legal Science.vol.03,2004.

[2] Chen Meixuan. From River Governor System to River Governor Management: On the Theoretical Basis and Practical Innovation of the River Governor Management, journal of central south university of forestry \& technology, vol.02, pp.6-11,2018.

\footnotetext{
${ }^{7}$ Wang Yong. The connotation of the country under the rule of law and the innovation of social governance, Journal of Zhejiang Party School of C.P.C,vol.03,2018.

${ }^{8} \mathrm{Li}$ Meicun. Study on long-term and effective path for pollution control by river-head system: case of Jiangsu Province, Yangtze River.vol.19,2017
} 
[3] Zhu Mei. On the Development and Promotion of River Governor System, Environmental Protection, vol.Z1, 2017.

[4] Wang Yong. The connotation of the country under the rule of law and the innovation of social governance, Journal of Zhejiang Party School of C.P.C, vol.03, 2018.

[5] Li Meicun. Study on long-term and effective path for pollution control by river-head system: case of Jiangsu Province, Yangtze River.vol.19, 2017. 